\title{
MORAL PHILOSOPHY AND POLITICS
}

$\begin{array}{ll}\text { GUEST EDITORS } & \text { FOUNDING EDITOR } \\ \text { Marcel van Ackeren } & \begin{array}{l}\text { Lukas H. Meyer } \\ \text { Mark Peacock } \\ \text { Simon Derpmann }\end{array} \\ \text { Peter Schaber } \\ \text { MANAGING EDITOR } & \text { Michael Schefczyk } \\ \text { Christoph Schmidt-Petri } & \\ & \\ \text { EDITORIAL BOARD } & \\ \text { Elizabeth Anderson } & \text { Matt Matravers } \\ \text { Arthur Applbaum } & \text { Kirsten Meyer } \\ \text { Dieter Birnbacher } & \text { David Miller } \\ \text { Rüdiger Bittner } & \text { Nenad Miscevic } \\ \text { Idil Boran } & \text { Susan Neiman } \\ \text { John Broome } & \text { Elif Özmen } \\ \text { Simon Caney } & \text { Nigel Pleasants } \\ \text { Paula Casal } & \text { Thomas Pogge } \\ \text { Stephen Darwall } & \text { Mathias Risse } \\ \text { Andreas Føllesdal } & \text { Sam Scheffler } \\ \text { Rainer Forst } & \text { Thomas Schmidt } \\ \text { Stephen Gardiner } & \text { Ralf Stoecker } \\ \text { Stefan Gosepath } & \text { Adam Swift } \\ \text { David Heyd } & \text { John Tasioulas } \\ \text { Wilfried Hinsch } & \text { Leif Wenar } \\ \text { Duncan Ivison } & \text { Andrew Williams } \\ \text { Rahel Jaeggi } & \text { Lea Ypi } \\ & \end{array}$

\section{DE GRUYTER}


ABSTRACTED/INDEXED IN Baidu Scholar · CNKI Scholar (China National Knowledge Infrastructure) - CNPIEC: cnpLINKer · Dimensions · EBSCO Discovery Service · Google Scholar .

J-Gate · JournalTOCs · KESLI-NDSL (Korean National Discovery for Science Leaders) · Microsoft Academic · Naviga (Softweco) - Norwegian Register for Scientific Journals, Series and Publishers · Philosopher's Index · PhilPapers · Primo Central (ExLibris) · ProQuest (relevant databases) · Publons · QOAM (Quality Open Access Market) · ReadCube · SCImago (SJR) · SCOPUS · Summon (Serials Solutions/ProQuest) · TDNet · Ulrich's Periodicals Directory/ulrichsweb · WanFang Data · WorldCat (OCLC)

The publisher, together with the authors and editors, has taken great pains to ensure that all information presented in this work (programs, applications, amounts, dosages, etc.) reflects the standard of knowledge at the time of publication. Despite careful manuscript preparation and proof correction, errors can nevertheless occur. Authors, editors and publisher disclaim all responsibility for any errors or omissions or liability for the results obtained from use of the information, or parts thereof, contained in this work.

ISSN 2194-5616 · e-ISSN 2194-5624

All information regarding notes for contributors, subscriptions, Open access, back volumes and orders is available online at www.degruyter.com/journals/mopp

RESPONSIBLE EDITORS Prof. Dr. Michael Schefczyk, Institut für Philosophie, Karlsruher Institut für Technologie (KIT), Douglasstraße 24, Viertes Obergeschoss, Raum 513, 76133 Karlsruhe, Germany, Tel.: +49 (0)721 608 - 42149, Email: michael.schefczyk@kit.edu

JOURNAL MANAGER Anna Barkhoff, De Gruyter, Genthiner Straße 13, 10785 Berlin, Germany, Tel.: +49 (0)30 26005 - 317, Fax: +49 (0)30 26005 - 250,

Email: anna.barkhoff@degruyter.com

RESPONSIBLE FOR ADVERTISEMENTS Claudia Neumann, De Gruyter, Genthiner Straße 13, 10785 Berlin, Germany, Tel.: +49 (0)30 26005 - 266, Fax: +49 (0)30 26005 - 264,

Email: anzeigen@degruyter.com

(C) 2019 Walter de Gruyter GmbH, Berlin/Boston

TYPESETTING Integra Software Services Pvt. Ltd., Pondicherry, India

PRINTING Franz X. Stückle Druck und Verlag e.K., Ettenheim

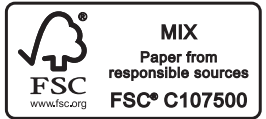




\section{Contents}

\section{Special Issue: Demandingness in Practice}

Guest Editors: Marcel van Ackeren and Simon Derpmann

Marcel van Ackeren and Simon Derpmann

Introduction to the Special Issue on Demandingness in Practice -1

Matthew H. Kramer

The Demandingness of Deontological Duties: Is the Absolute Impermissibility of Placatory Torture Irrational? - 9

Anna Hartford

How Much Should a Person Know? Moral Inquiry \& Demandingness - 41

Alberto Giubilini and Julian Savulescu

Demandingness and Public Health Ethics -65

Kian Mintz-Woo

Principled Utility Discounting Under Risk — 89

Brian Berkey

Collective Obligations and Demandingness Complaints - 113

\section{Articles}

Luke Maring

Which Borders? - 133

Rudolf Schuessler

Sufficientarianism and the Measurement of Inequality -147

Matthias Brinkmann

Indirect Instrumentalism about Political Legitimacy — 175 